\title{
Analisis Efektifitas dan Kontribusi Pendapatan Asli Daerah (PAD) Kota Banda Aceh
}

\author{
Dahlia \\ Program Studi Analis Keuangan, Politeknik Kutaraja
}

\begin{abstract}
Abstrak. Penelitian ini bertujuan untuk mengetabui tingkat efektifitas pungutan sumber Pendapatan Asli Daerah (PAD), yaitu pajak daerah, retribusi daerah, laba perusabaan daerah, dan lain-lain pendapatan yang sah yang dikelola oleh Dinas Pendapatan Kota Banda Aceh. Sekaligus juga menganalisis apakah pajak daerah, retribusi daerah, laba perusahaan daerah, dan lain-lain pendapatan yang sah tersebut berkontribusi dalam meningkatkan Pendapatan Asli Daerah (PAD) di kota Banda Aceh. Analisis data yang digunakan dalam penelitian ini yaitu analisis rasio efektivitas dan analisis kontribusi. Untuk keperluan analisis digunakan data sekunder dengan periode tabun 2007-2011. Hasil penelitian ini mengungkapkan bahwa, secara rata-rata tingkat efektivitas berada pada kategori sangat efektif untuk pajak daerah, efektif untuk retribusi daerah, kurang efektif untuk. laba perusabaan daerah, dan sangat efektif untuk. lain-lain pendapatan yang sah. Sementara untuk analiss kontribusi, secara ratarata tingkat kontribusi pajak daerah, retribusi daerah, laba perusabaan daerah, dan lain-lain pendapatan yang sab berada pada kategori baik untuk pajak daerah, sedang untuk retribusi daerah, sangat kurang untuk laba perusahaan daerah, dan sedang untuk lain-lain pendapatan yang sah.
\end{abstract}

Kata kunci: Pendapatan Asli Daerah, Efektifitas, dan Kontribusi.

Abstract. This study aims to determine the effectiveness of the collection of sources of Regional Original Revenue $(P A D)$, namely local taxes, regional levies, regional company profits, and other legitimate income managed by the Banda Aceh City Revenue Service. At the same time, it also analyzes whether local taxes, regional levies, regional company profits, and other legitimate income contribute to increasing PAD in Banda Aceh. Data analysis used in this study is effectiveness ratio analysis and contribution analysis. For the purposes of analysis, secondary data is used for the period 2007-2011. The results of this study reveal that, on average, the level of effectiveness is in the very effective category for local taxes, effective for regional retribution, less effective for regional company profits, and very effective for other legitimate income. While for analyzing contributions, on average the level of contribution of local taxes, regional retribution, regional company profits, and other legitimate income is in the category of good for local taxes, moderate for regional retribution, very less for regional company profits, and medium for other legitimate income.

Keywords: Regional Original Income, Effectiveness, and Contributions.

*Corresponding author. Email: dahlia@politeknikkutaraja.ac.id 


\section{Pendahuluan}

Kemandirian daerah sangat ditentukan oleh besarnya Pendapatan Asli Daerah (PAD). Undang-undang No. 33 Tahun 2004 tentang Perimbangan Keuangan antara Pemerintah Pusat dan Pemerintah Daerah menyebutkan, yang dimaksud dengan PAD adalah pendapatan yang diperoleh daerah untuk mendanai kebutuhan daerah dalam rangka pelaksanaan desentralisasi. Dalam Bab IV pasal 5 Undangundang No. 33 Tahun 2004 tentang Perimbangan Keuangan antara Pemerintah Pusat dan Pemerintah Daerah disebutkan bahwa sumber penerimaan daerah dalam rangka pelaksanaan desentralisasi terdiri atas pendapatan daerah dan pembiayaan.

Pendapatan daerah dapat berasal dari pendapatan asli daerah, dana perimbangan, dan lain-lain pendapatan. Sedangkan pembiayaan bersumber dari sisa lebih perhitungan anggaran daerah tahun sebelumnya, penerimaan pinjaman daerah, dana cadangan daerah dan penjualan kekayaan daerah yang dipisahkan. Tanpa pendapatan yang mencukupi hampir mustahil suatu daerah otonom dapat berkembang serta meningkatkan pelayanan publik dalam segala sektor. Dengan kata lain semakin besar PAD suatu daerah maka ketergantungannya terhadap pusat semakin berkurang dan sebaliknya dapat pula diartikan bila PAD suatu daerah masih rendah sebagai indikasi bahwa peran pemerintah daerah tersebut masih sangat kurang.

Dalam Undang-undang No.11 tahun 2006 tentang Pemerintah Aceh, sangat sedikit ditemui pasal-pasal yang mengatur tentang hal keuangan. Penjelasan Undang-undang Pemerintah Aceh (UUPA) kebanyakan mengenai urusan pemerintahan. Sehingga untuk hal yang berkenaan dengan keuangan daerah masih merujuk pada UU No.33 Tahun 2004 tentang Perimbangan Keuangan antara Pemerintah Pusat dan Pemerintah Daerah.

Setiap awal tahun anggaran, kota Banda Aceh melalui Tim Anggaran Pemerintah Daerah beserta DPRK dalam menyusun dan menetapkan Anggaran Pendapatan dan Belanja Daerah serta target masing-masing komponen penerimaan PAD harus mempertimbangkan kondisi perekonomian dan keamanan. Situasi politik dan kondisi perekonomian yang kondusif merupakan hal penting dalam menetapkan target penerimaan. Kegiatan ekonomi melaju pesat dengan ditopang oleh kestabilan kondisi sosial politik daerah yang akan menentukan dan memberi peluang bagi kota Banda Aceh untuk mengoptimalkan pencapaian target penerimaan serta leluasa untuk menggali sumber-sumber penerimaan PAD lainnya.

Untuk membiayai kegiatan pembangunan kota Banda Aceh, selain mengandalkan dana perimbangan (Dana Bagi Hasil, DAU, dan DAK) dan Lain-lain Pendapatan yang Sah, juga dibiayai dari penerimaan daerah yang bersumber dari PAD. PAD merupakan sumber pendanaan penting untuk daerah. Dengan penerimaan PAD yang relative kecil akan sulit bagi daerah tersebut untuk melaksanakan proses penyelenggaraan pemerintah dan pembangunan secara mandiri. Dalam rangka terwujudnya ekonomi daerah yang nyata dan bertanggungjawab, maka pemerintah kota Banda Aceh harus sekuat tenaga berusaha meningkatkan PAD dan mencari sumber-suber PAD yang potensial.

\section{Tinjauan Literatur}

Halim (2001:19) memaknai keuangan daerah sebagai senua hak dan kewajiban yang dapat dinilai dengan uang, demikian pula segala sesuatu baik berupa uang maupun barang yang dapat dijadikan kekayaan daerah sepanjang itu belum dimilki/ dikuasai oleh negara serta pihakpihak lain sesuai ketentuan/ peraturan undangundang yang berlaku. Menurut Mardiasmo (2002), PAD adalah penerimaan daerah dari sektor pajak daerah, retribusi daerah, hasil perusahaan milik daerah, hasil pengelolaan kekayaan daerah yang dipisahkan, dan lain-lain PAD yang sah.

Sumitro (1991:12), pajak adalah peralihan kekayaan dari sektor swasta ke sektor publik berdasarkan UU yang dapat dipaksakan dengan tidak mendapat imbalan (tehenprestatie) yang secara langsung dapat ditunjukkan, yang digunakan untuk membiayai pengeluaran umum dan sebagai pendorong, penghambat atau pencegah untuk mencapai tujuan yang ada diluar bidang keuangan.

Sedangkan untuk retribusi, berbagai defenisi 
retribusi daerah telah diutarakan oleh para ahli diantaranya, menurut Soemitro dan Kaho (1991:151), yaitu sebagai pembayaranpembayaran kepada Negara yang dilakukan oleh mereka yang menggunakan jasa-jasa negara. retribusi daerah pada dasarnya dapat dipaksakan secara ekonomis, apabila sipembayar retribusi tidak dpat merasakan langsung manfaat dari retribusi daerah tersebut. Sedangkan mereka yang tidak merasakan nikmat langsung dari retribusi tidak dapat dipaksakan pengenaannya.

Menurut Undang-undang No. 32 Tahun 2004 tentang Pemerintah Daerah, sumber-sumber pendapatan asli daerah yaitu: Pendapatan Asli Daerah (PAD) yang terdiri atas:

a. Hasil Pajak Daerah, menurut UU No.28 Tahun 2004 tentang Pemerintah Daerah, dan Retribusi Daerah, yang selanjutnya disebut pajak, adalah kontribusi wajib kepada daerah yang terutang oleh orang pribadi atau badan yang bersifat memaksa berdasarkan Undang-undang, dengan tidak mendapatkan imbalan secara langsung dan digunakan untuk keperluan daerah bagi sebesar-besarnya kemakmuran rakyat.

b. Hasil retribusi daerah, menurut UU No. 28 Tahun 2009 tentang Pajak Daerah dan Retribusi daerah, selanjutnya disebut retribusi, adalah pungutan daerah sebagai pembayaran atas jasa atau pemberian izin tertentu yang khusus disediakan dan/atau diberikan oleh Pemerintah Daerah untuk kepentingan orang pribadi atau badan.

c. Hasil perusahaan milik daerah dan hasil pengelolaan kekayaan daerah yang dipisahkan adalah hasil pendapatan daerah dari keuntungan yang didapat dari perusahaan daerah yang dapat berupa dana pembangunan daerah dan merupakan bagian untuk anggaran belanja daerah yang disetor ke kas daerah. Hasil perusahaan milik daerah dan hasil pengelolaan kekayaan daerah lainnya yang dipisahkan antara lain: bagian laba, deviden, dan penjualan saham milik daerah.

d. Lain-lain pendapatan yang sah berupa jasa giro, penjualan aset tetap daerah, pendapatan bunga, keuntungan selisih nilai rupiah terhadap mata uang asing, komisi, potongan, dan bentuk lain sebagai akibat dari penjualan atau pengadaan barang dan jasa oleh daerah.

\section{Metodologi Penelitian}

\section{Analisis Kontribusi dan Rasio Efektifitas Analisis Kontribusi}

Analisis kontribusi yaitu suatu analisis yang digunakan untuk mengetahui seberapa besar kontribusi yang dapat disumbangkan dari penerimaan sumber-sumber pendapatan daerah, yaitu dari pajak daerah, retribusi daerah, laba perusahaan daerah, dan lain-lain pendapatan asli daerah yang sah, terhadap pendapatan asli daerah, dibandingkan dengan realisasi penerimaan Pendapataan Asli Daerah (PAD).

1. Analisis Kontribusi Pajak Daerah

$$
=\frac{K_{P D}}{\text { Realisasi Penerimaan Pajak Daerah }} \times 100 \%
$$

2. Analisis Kontribusi Retribusi Daerah

$K_{R D}$

$=\frac{\text { Realisasi Penerimaan Retribusi Daerah }}{\text { Realisasi PAD }} \times 100 \%$

3. Analisis Kontribusi Laba Perusahaan Daerah

$K_{L P D}$

$=\frac{\text { Realisasi Penerimaan Laba Perusahaan Daerah }}{\text { Realisasi PAD }} \times 100 \%$

4. Analisis Kontribusi Lain-lain Pendapatan Asli Daerah yang Sah

$K_{\text {LLPS }}$

$=\frac{\text { Realisasi Penerimaan Lain }- \text { lain Pendapatan Daerah yang Sah }}{\text { Realisasi PAD }} \times 100 \%$

Dimana kriteria kontribusi pajak daerah, retribusi daerah, laba perusahaan daerah, dan lain-lain pendapatan yang sah, dinyatakan sangat baik apabila rasionya mencapai diatas $50 \%$. Dapat dilihat dalam tabel berikut ini. 
Tabel 1. Kriteria Kontribusi Keuangan

\begin{tabular}{cc}
\hline $\begin{array}{c}\text { Persentase Kinerja } \\
\text { Keuangan }\end{array}$ & Kriteria \\
\hline$>100 \%$ & Sangat efektif \\
$90 \%-100 \%$ & Efektif \\
$80 \% 90 \%$ & Cukup efektif \\
$60 \%-80 \%$ & Kurang efektif \\
$<60 \%$ & Tidak efektif \\
\hline
\end{tabular}

Sumber: Depdagri dengan Kepmendagri No.690.900.327 Tahun 1996

\section{Rasio Efektifitas}

Rasio efektivitas pajak daerah adalah rasio yang menggambarkan kemampuan pemerintah daerah dalam merealisasikan pendapatan asli daerah yang diperoleh dari sumber-sumebr pendapatan asli daerah, yaitu pajak daerah, retribusi daerah, laba perusahaan daerah, dan lain-lain pendapatan asli daerah yang direncanakan, dibandingkan dengan yang ditetapkan berdasarkan potensi riil daerah.

1. Rasio Efektivitas Pajak Daerah

$$
\begin{aligned}
& \text { Rasio Efektivitas } \\
& =\frac{\text { Realisasi Pajak Daerah }}{\text { Target pajak Daerah }} \times 100 \%
\end{aligned}
$$

2. Rasio Efektifitas Retribusi Daerah

$$
\begin{aligned}
& \text { Rasio Efektivitas } \\
& =\frac{\text { Realisasi Retribusi Daerah }}{\text { Target Retribusi Daerah }} \times 100 \%
\end{aligned}
$$

3. Rasio Efektifitas Laba Perusahaan Daerah.

\section{Rasio Efektivitas}

$=\frac{\text { Realisasi Laba Perusahaan Daerah }}{\text { Target Laba Perusahaan Daerah }} \times 100 \%$

4. Rasio Efektifitas Lain-lain Pendapatan Asli yang Sah

Rasio efektivitas laba perusahaan adalah rasio yang menggambarkan kemampuan daerah dalam merealisasikan pendapatan asli daerah yang diperoleh dari laba perusahaan daerah yang direncanakan, dibandingkan dengan dengan target yang ditetapkan berdasarkan potensi riil daerah.

Rasio Efektivitas

$=\frac{\text { Realisasi Lain }- \text { lain Pendapatan yang Sah }}{\text { Target Lain }- \text { lain Pendapatan yang Sah }} \times 100 \%$
Dimana efektifitas pemungutan pajak daerah, retribusi daerah, laba perusahaan daerah, dan lain-lain pendapatan yang sah, dinyatakan efektif apabila rasionya mencapai 100\%. Dapat dilihat dalam tabel berikut ini.

Tabel 2. Kriteria Kinerja Keuangan (efektifitas)

\begin{tabular}{cc}
\hline $\begin{array}{c}\text { Persentase Kinerja } \\
\text { Keuangan }\end{array}$ & Kriteria \\
\hline $0,00 \%-10 \% \%$ & Sangat Kurang \\
$10,10 \%-20 \%$ & Kurang \\
$20,10 \%-30 \%$ & Sedang \\
$30,10 \%-40 \%$ & Cukup Baik \\
$40,10 \%-50 \%$ & Baik \\
$<50 \%$ & Sangat Baik \\
\hline
\end{tabular}

Sumber: Depdagri dengan Kepmendagri No.690.900.327 Tahun 1996

\section{Analisa dan Pembahasan}

\section{Analisis Efektivitas Pajak Daerah Kota Banda Aceh}

Rasio efektivitas pajak daerah adalah rasio yang menggambarkan kemampuan pemerintah daerah dalam merealisasikan pendapatan asli daerah yang diperoleh dari pajak daerah yang direncanakan, dibandingkan dengan yang ditetapkan berdasarkan potensi riil daerah.

\begin{tabular}{|c|c|c|c|c|}
\hline $\begin{array}{c}\text { Tah } \\
\text { un }\end{array}$ & $\begin{array}{c}\text { Target } \\
\text { (Rp) }\end{array}$ & $\begin{array}{c}\text { Realisasi } \\
\text { (RP) }\end{array}$ & $\begin{array}{c}\text { Efektiv } \\
\text { itas } \\
\text { Pajak } \\
\text { Daerah } \\
\quad(\%)\end{array}$ & $\begin{array}{c}\text { Kriteria } \\
\text { Efektiv } \\
\text { itas }\end{array}$ \\
\hline 2007 & $\begin{array}{c}13.920 .000 \\
.000\end{array}$ & $\begin{array}{c}15.812 .025 \\
.530\end{array}$ & 113,59 & $\begin{array}{l}\text { Sangat } \\
\text { Efektif }\end{array}$ \\
\hline 2008 & $\begin{array}{c}23.303 .000 \\
.000\end{array}$ & $\begin{array}{c}25.518 .334 \\
.146\end{array}$ & 109,51 & $\begin{array}{l}\text { Sangat } \\
\text { Efektif }\end{array}$ \\
\hline 2009 & $\begin{array}{c}24.581 .820 \\
.000\end{array}$ & $\begin{array}{c}27.457 .923 \\
.297\end{array}$ & 111,70 & $\begin{array}{l}\text { Sangat } \\
\text { Efektif }\end{array}$ \\
\hline 2010 & $\begin{array}{c}25.673 .074 \\
.261\end{array}$ & $\begin{array}{c}28.035 .595 \\
.086\end{array}$ & 109,2 & $\begin{array}{l}\text { Sangat } \\
\text { Efektif }\end{array}$ \\
\hline 2011 & $\begin{array}{c}27.286 .514 \\
.939 \\
\text { Rata-rat }\end{array}$ & $\begin{array}{c}33.549 .809 \\
.961 \\
\end{array}$ & $\begin{array}{l}122,95 \\
\mathbf{1 1 3 , 3 9}\end{array}$ & $\begin{array}{l}\text { Sangat } \\
\text { Efektif } \\
\text { Sangat } \\
\text { Efektif }\end{array}$ \\
\hline
\end{tabular}

$$
\begin{aligned}
& \text { Rasio Efektivitas } \\
& =\frac{\text { Realisasi Pajak Daerah }}{\text { Target pajak Daerah }} \times 100 \%
\end{aligned}
$$

Tabel 3. Efektivitas Pajak Daerah Kota Banda Aceh Tahun 2007-2011

Sumber: Dinas Pendapatan Kota Banda Aceh (diolah). 


\section{Analisis Efektivitas Retribusi Daerah Kota Banda Aceh}

Rasio efektivitas retribusi daerah adalah rasio yang menggambarkan kemampuan daerah dalam merealisasikan pendapatan asli daerah yang diperoleh dari retribusi daerah yang direncanakan, dibandingkan dengan dengan target yang ditetapkan berdasarkan potensi riil daerah

\section{Rasio Efektivitas$$
=\frac{\text { Realisasi Retribusi Daerah }}{\text { Target Retribusi Daerah }} \times 100 \%
$$

Tabel 4. Efektivitas Retribusi Daerah Kota Banda Aceh Tahun 2007-2011

\begin{tabular}{|c|c|c|c|c|}
\hline Tahun & $\begin{array}{c}\text { Target } \\
\text { (Rp) }\end{array}$ & $\begin{array}{c}\text { Realisasi } \\
\text { (Rp) }\end{array}$ & $\begin{array}{c}\text { Efektivitas } \\
\text { Pajak Daerah } \\
(\%)\end{array}$ & $\begin{array}{c}\text { Kriteria } \\
\text { Efektivitas }\end{array}$ \\
\hline 2007 & 7.515 .649 .897 & 6.930 .661 .811 & 92,22 & Efektif \\
\hline 2008 & 13.024 .624 .500 & 8.644 .628 .092 & 66,37 & Efektif \\
\hline 2009 & 14.522 .560 .000 & 10.522 .701 .892 & 72,46 & Efektif \\
\hline 2010 & 16.978 .805 .000 & 12.146.641.942 & 71,54 & Efektif \\
\hline 2011 & 17.592 .853 .241 & 14.797 .836 .701 & 84,11 & Efektif \\
\hline & Rata-rata & & 77,34 & Efektif \\
\hline
\end{tabular}

Sumber: Dinas Pendapatan Kota Banda Aceh (diolah).

\section{Analisis Rasio Efektivitas Laba Perusahaan Daerah.}

Rasio efektivitas laba perusahaan adalah rasio yang menggambarkan kemampuan daerah dalam merealisasikan pendapatan asli daerah yang diperoleh dari laba perusahaan daerah yang direncanakan, dibandingkan dengan dengan target yang ditetapkan berdasarkan potensi riil daerah.

\section{Rasio Efektivitas \\ $=\frac{\text { Realisasi Laba Perusahaan Daerah }}{\text { Target Laba Perusahaan Daerah }} \times 100 \%$}

Tabel 5. Efektivitas Retribusi Daerah Kota Banda Aceh Tahun 2007-2011

\begin{tabular}{|c|c|c|c|c|}
\hline Tahun & $\begin{array}{c}\text { Target } \\
\left(R_{p}\right)\end{array}$ & $\begin{array}{c}\text { Realisasi } \\
\text { (RP) }\end{array}$ & $\begin{array}{c}\text { Efektivitas } \\
\text { Pajak Daerah } \\
(\%)\end{array}$ & $\begin{array}{c}\text { Kriteria } \\
\text { Efektivitas }\end{array}$ \\
\hline 2007 & 1.937 .900 .000 & 769.657 .037 & 39,72 & Tidak Efektif \\
\hline 2008 & 1.000 .000 .000 & 719.261 .211 & 71,93 & Kurang Efektif \\
\hline 2009 & 1.000 .000 .000 & 720.441 .021 & 72,04 & Kurang Efektif \\
\hline 2010 & 720.441 .021 & 655.113 .816 & 90,93 & Efektif \\
\hline 2011 & 720.441 .021 & 483.671 .741 & 67.14 & Kurang Efektif \\
\hline
\end{tabular}

Sumber: Dinas Pendapatan Kota Banda Aceh (diolah).

\section{Analisis Rasio Efektivitas Lain-lain PAD yang Sah.}

Rasio efektivitas laba perusahaan adalah rasio yang menggambarkan kemampuan daerah dalam merealisasikan pendapatan asli daerah yang diperoleh dari lain-lain PAD yang sah yang direncanakan, dibandingkan dengan dengan target yang ditetapkan berdasarkan potensi riil daerah.

Rasio Efektivitas
$=\frac{\text { Realisasi Lain - lain Pendapatan yang Sah }}{\text { Target Lain - lain Pendapatan yang Sah }} \times 100 \%$

Tabel 6. Efektivitas Lain-lain PAD yang Sah Kota Banda Aceh Tahun 2007-2011

\begin{tabular}{|c|c|c|c|c|}
\hline Tahun & $\begin{array}{c}\text { Target } \\
\text { (Rp) }\end{array}$ & $\begin{array}{c}\text { Realisasi } \\
\text { (RP) }\end{array}$ & $\begin{array}{c}\text { Efektivitas } \\
\text { Pajak } \\
\text { Daerah } \\
(\%)\end{array}$ & $\begin{array}{c}\text { Kriteria } \\
\text { Efektivitas }\end{array}$ \\
\hline 2007 & 8.951 .158 .000 & 7.346 .688 .044 & 82,08 & Cukup Efektif \\
\hline 2008 & 7.672.375.500 & 8.215.480.912 & 107,08 & Sangat Efektif \\
\hline 2009 & 10.272 .495 .000 & 10.577 .530 .395 & 102,97 & Sangat Efektif \\
\hline 2010 & 720.441 .012 & 11.411 .640 .408 & 120,98 & Sangat Efektif \\
\hline 2011 & 26.642 .392 .025 & 27.727 .071 .217 & 104,07 & Sangat Efektif \\
\hline & Rata-rata & & 103,44 & Sangat Efektif \\
\hline
\end{tabular}

Sumber: Dinas Pendapatan Kota Banda Aceh (diolah).

Tabel 7. Analisis Efektifitas Sumber-sumber PAD Kota Banda Aceh Tahun 2007-2011

\begin{tabular}{|c|c|c|c|c|c|c|c|c|}
\hline \multirow[b]{2}{*}{ Tahum } & \multicolumn{2}{|c|}{ Pajak Daerah } & \multicolumn{2}{|c|}{ Retribusi Daerah } & \multicolumn{2}{|c|}{ Laba Perusahaaan } & \multicolumn{2}{|c|}{ Lain-lain PAD yang Sah } \\
\hline & Efekrifitas & Kniteria & Efektifitas & Kniteria & Efektifitas & Kriteria & Efektifitas & Kniteria \\
\hline 2007 & 113,59 & $\begin{array}{l}\text { Sangat } \\
\text { Efektif }\end{array}$ & 92,22 & Efektif & 39,72 & $\begin{array}{l}\text { Tidak } \\
\text { Efektif }\end{array}$ & 82,08 & $\begin{array}{l}\text { Cukup } \\
\text { Efektif }\end{array}$ \\
\hline 2008 & 109,51 & $\begin{array}{l}\text { Sangat } \\
\text { Efektif }\end{array}$ & 66,37 & Efektif & 71,93 & $\begin{array}{l}\text { Kurang } \\
\text { Efektif }\end{array}$ & 107,08 & $\begin{array}{l}\text { Sangat } \\
\text { Efektif }\end{array}$ \\
\hline 2009 & 111,70 & $\begin{array}{l}\text { Sangat } \\
\text { Efektif }\end{array}$ & 72,46 & Efektif & 72,04 & $\begin{array}{l}\text { Kurang } \\
\text { Efektif }\end{array}$ & 102,97 & $\begin{array}{l}\text { Sangat } \\
\text { Efektif }\end{array}$ \\
\hline 2010 & 109,2 & $\begin{array}{l}\text { Sangat } \\
\text { Efeektif }\end{array}$ & 71,54 & Efektif & 90,93 & Efektif & 120,98 & $\begin{array}{l}\text { Sangat } \\
\text { Efektif }\end{array}$ \\
\hline 2011 & 122,95 & $\begin{array}{l}\text { Sangat } \\
\text { Efektif }\end{array}$ & 84,11 & Efektif & 67.14 & $\begin{array}{l}\text { Kurang } \\
\text { Efektif }\end{array}$ & 104,07 & $\begin{array}{l}\text { Sangat } \\
\text { Efektif }\end{array}$ \\
\hline $\begin{array}{c}\text { Rata- } \\
\text { rata }\end{array}$ & 113,39 & $\begin{array}{l}\text { Sangat } \\
\text { Efektif }\end{array}$ & 77,34 & Efektif & 68,35 & $\begin{array}{l}\text { Kurang } \\
\text { Efektif }\end{array}$ & 103,44 & $\begin{array}{l}\text { Sangat } \\
\text { Efektif }\end{array}$ \\
\hline
\end{tabular}

\section{Analisi Rasio Efektifitas Pendapatan Asli Daerah}

Rasio efektivitas pendapatan Asli Daerah adalah rasio yang menggambarkan kemampuan daerah dalam merealisasikan pendapatan asli daerah yang direncanakan, dibandingkan dengan target yang ditetapkan.

\section{Rasio Efektivitas $=\frac{\text { Realisasi Pendapatan Asli Daerah }}{\text { Target Pendapatan Daerah }} \times 100 \%$}

\section{Analisis Kontribusi Sumber PAD Kota Banda Aceh}

Analisis kontribusi yaitu suatu analisis yang digunakan untuk mengetahui seberapa besar kontribusi yang dapat disumbangkan dari penerimaan sumber-sumber pendapatan daerah, yaitu dari pajak daerah, retribusi daerah, laba perusahaan daerah, dan lain-lain pendapatan asli daerah yang sah, terhadap pendapatan asli daerah, dibandingkan dengan realisasi penerimaan Pendapataan Asli Daerah (PAD). 
Analisis Kontribusi Pajak Daerah

Tabel 8. Efektivitas Pajak Daerah Kota Banda Aceh Tahun 2007-2011

\begin{tabular}{ccccc}
\hline Tahun & $\begin{array}{c}\text { Realisasi } \\
\text { Pajak Daerah } \\
(\text { Rp) }\end{array}$ & $\begin{array}{c}\text { Realisasi } \\
\text { PAD } \\
(\text { RP) }\end{array}$ & $\begin{array}{c}\text { Kontribusi } \\
\text { Pajak Daerah } \\
(\%)\end{array}$ & $\begin{array}{c}\text { Kriteria } \\
\text { Kontribusi }\end{array}$ \\
\hline 2007 & 15.812 .025 .530 & 30.859 .032 .422 & 51,24 & Sangat Baik \\
2008 & 25.518 .334 .146 & 43.097 .704 .361 & 59,21 & Sangat Baik \\
2009 & 27.457 .923 .297 & 49.278 .596 .596 & 55,72 & Sangat Baik \\
2010 & 28.035 .595 .086 & 52.804 .612 .773 & 53.09 & Sangat Baik \\
2011 & 33.549 .809 .961 & 85.560 .389 .620 & 39,21 & Cukup Baik \\
& Rata-rata & & $\mathbf{4 9 , 8 4}$ & Baik \\
\hline
\end{tabular}

Sumber: Dinas Pendapatan Kota Banda Aceh (diolah).

\section{Analisis Kontribusi Retribusi Daerah}

Tabel 9. Kontribusi Retribusi Daerah Kota

\begin{tabular}{|c|c|c|c|c|}
\hline Tahun & $\begin{array}{c}\text { Realisasi } \\
\text { Retribusi Daerah } \\
\text { (Rp) }\end{array}$ & $\begin{array}{c}\text { Realisasi } \\
\text { PAD } \\
\text { (RP) }\end{array}$ & $\begin{array}{c}\text { Kontribusi } \\
\text { Retribusi } \\
\text { Daerah } \\
(\%)\end{array}$ & $\begin{array}{c}\text { Kriteria } \\
\text { Kontribusi }\end{array}$ \\
\hline 2007 & 6.930 .661 .811 & 30.859 .032 .422 & 22.46 & Sedang \\
\hline 2008 & 8.644 .628 .092 & 43.097 .704 .361 & 20.06 & Sedang \\
\hline 2009 & 10.522 .701 .892 & 49.278 .596 .596 & 21.35 & Sedang \\
\hline 2010 & 12.146 .641 .942 & 52.804 .612 .773 & 23.00 & Sedang \\
\hline 2011 & 14.797 .836 .701 & 85.560 .389 .620 & 17.30 & Kurang \\
\hline & Rata-rata & & 20.28 & Sedang \\
\hline
\end{tabular}

Sumber: Dinas Pendapatan Kota Banda Aceh (diolah).

\section{Analisis Kontribusi Laba Perusahaan Daerah}

Tabel 10. Kontribusi Laba Perusahaan Daerah Kota Banda Aceh Tahun 2007-2011

\begin{tabular}{|c|c|c|c|c|}
\hline Tahun & $\begin{array}{c}\text { Realisasi } \\
\text { Laba Perusahaan } \\
\text { Daerah } \\
\left(R_{p}\right)\end{array}$ & $\begin{array}{c}\text { Realisasi } \\
\text { PAD }\end{array}$ & $\begin{array}{c}\text { Kontribusi } \\
\text { Laba } \\
\text { Perusahaan } \\
\text { Daerah } \\
(\%)\end{array}$ & $\begin{array}{c}\text { Kriteria } \\
\text { Kontribusi }\end{array}$ \\
\hline 2007 & 769.657 .037 & 30.859 .032 .422 & 2.50 & Sangat Kurang \\
\hline 2008 & 719.261 .211 & 43.097 .704 .361 & 1,67 & Sangat Kurang \\
\hline 2009 & 720.441 .021 & 49.278 .596 .596 & 1,46 & Sangat Kurang \\
\hline 2010 & 655.113 .816 & 52.804 .612 .773 & 1,24 & Sangat Kurang \\
\hline \multirow[t]{2}{*}{2011} & 483.671 .741 & 85.560 .389 .620 & 0,56 & Sangat Kurang \\
\hline & Rata-rata & & 1,49 & Sangat Kurang \\
\hline
\end{tabular}

Sumber: Dinas Pendapatan Kota Banda Aceh (diolah).

\section{Analisis Kontribusi Lain-lain Pendapatan yang Sah}

Tabel 11. Kontribusi Lain-lain Pendapatan yang

Sah Kota Banda Aceh Tahun 2007-2011

\begin{tabular}{ccccc}
\hline Tahun & $\begin{array}{c}\text { Realisasi } \\
\text { Lain-lain } \\
\text { Pendapatan yang } \\
\text { Sah (Rp) }\end{array}$ & $\begin{array}{c}\text { Realisasi } \\
\text { PAD }\end{array}$ & $\begin{array}{c}\text { Kontribusi } \\
\text { Lain-lain } \\
\text { Pendapatan }\end{array}$ & $\begin{array}{c}\text { Kriteria } \\
\text { Kontribusi }\end{array}$ \\
\hline 2007 & 7.346 .688 .044 & 30.859 .032 .422 & 23.81 & Sedang \\
2008 & 8.215 .480 .912 & 43.097 .704 .361 & 19.06 & Kurang \\
2009 & 10.577 .530 .395 & 49.278 .596 .596 & 21.46 & Sedang \\
2010 & 11.411 .640 .408 & 52.804 .612 .773 & 21.61 & Sedang \\
2011 & 27.727 .071 .217 & 85.560 .389 .620 & 32.41 & Cukup Baik \\
& Rata-rata & & 23.67 & Sedang \\
\hline
\end{tabular}

Sumber: Dinas Pendapatan Kota Banda Aceh (diolah).

\section{Simpulan}

Berdasarkan hasil penelitian dan pembahasan maka dapat diambil beberapa kesimpulan sebagai berikut:

1. Hasil analisis rasio efektifitas pajak daerah, retribusi daerah, laba perusahaan daerah, dan lain-lain pendapatan asli daerah yang sah, dapat disimpulkan bahwa secara rata-rata tingkat efektivitas berada pada kategori sangat efektif untuk pajak daerah, efektif untuk retribusi daerah, kurang efektif untuk laba perusahaan daerah, dan sangat efektif untuk lain-lain pendapatan yang sah.

2. Hasil analisis kontribusi pajak daerah, retribusi daerah, laba perusahaan daerah, dan lain-lain pendapatan yang sah, dapat disimpulkan bahwa secara rata-rata tingkat kontribusi pajak daerah, retribusi daerah, laba perusahaan daerah, dan lain-lain pendapatan yang sah berada pada kategori baik untuk pajak daerah, sedang untuk retribusi daerah, sangat kurang untuk laba perusahaan daerah, dan sedang untuk lain-lain pendapatan yang sah.

Tabel 12. Analisis Kontribusi Sumber-sumber PAD Kota Banda Aceh Tahun 2007-2011

\begin{tabular}{|c|c|c|c|c|c|c|c|c|}
\hline \multirow{2}{*}{ Tahun } & \multicolumn{2}{|c|}{ Pajak Daerah } & \multicolumn{2}{|c|}{ Retribusi Daerah } & \multicolumn{2}{c|}{$\begin{array}{c}\text { Laba Perusahaaan } \\
\text { Daerah }\end{array}$} & \multicolumn{2}{c|}{$\begin{array}{c}\text { Lain-lain PAD yang } \\
\text { Sah }\end{array}$} \\
\cline { 2 - 9 } & $\begin{array}{c}\text { Kontribusi } \\
(\%)\end{array}$ & Kriteria & $\begin{array}{c}\text { Kontribusi } \\
(\%)\end{array}$ & Kriteria & $\begin{array}{c}\text { Kontribusi } \\
(\%)\end{array}$ & Kriteria & $\begin{array}{c}\text { Kontribusi } \\
(\%)\end{array}$ & Kriteria \\
\hline 2007 & 51,24 & $\begin{array}{c}\text { Sangat } \\
\text { Baik }\end{array}$ & 22.46 & Sedang & 2.50 & $\begin{array}{c}\text { Sangat } \\
\text { Kurang }\end{array}$ & 23.81 & Sedang \\
\hline 2008 & 59,21 & $\begin{array}{c}\text { Sangat } \\
\text { Baik }\end{array}$ & 20.06 & Sedang & 1,67 & $\begin{array}{c}\text { Sangat } \\
\text { Kurang }\end{array}$ & 19.06 & Kurang \\
\hline 2009 & 55,72 & $\begin{array}{c}\text { Sangat } \\
\text { Baik }\end{array}$ & 21.35 & Sedang & 1,46 & $\begin{array}{c}\text { Sangat } \\
\text { Kurang }\end{array}$ & 21.46 & Sedang \\
\hline 2010 & 53.09 & $\begin{array}{c}\text { Sangat } \\
\text { Baik }\end{array}$ & 23.00 & Sedang & 1,24 & $\begin{array}{c}\text { Sangat } \\
\text { Kurang }\end{array}$ & 21.61 & Sedang \\
\hline 2011 & 39,21 & $\begin{array}{c}\text { Cukup } \\
\text { Baik }\end{array}$ & 17.30 & Kurang & 0,56 & $\begin{array}{c}\text { Sangat } \\
\text { Kurang }\end{array}$ & 32.41 & $\begin{array}{c}\text { Cukup } \\
\text { Baik }\end{array}$ \\
\hline $\begin{array}{c}\text { Rata- } \\
\text { rata }\end{array}$ & $\mathbf{4 9 , 8 4}$ & Baik & $\mathbf{2 0 . 2 8}$ & Sedang & $\mathbf{1 , 4 9}$ & $\begin{array}{c}\text { Sangat } \\
\text { Kurang }\end{array}$ & $\mathbf{2 3 . 6 7}$ & Sedang \\
\hline
\end{tabular}




\section{Daftar Pustaka}

Halim, Abdul. 2001. Manajemen Keuangan, Edisi Revisi, Penerbit Salemba Empat.

Indonesia, P.R., 2004. Undang-Undang Republik Indonesia Nomor 32 Tahun 2004 Tentang Pemerintahan Daerah. Jakarta (ID): RI.

Indonesia, R. and No, U.U., 32. Tahun 2004 tentang. Pemerintah Daerah. Jakarta.

Indonesia, Undang-undang No 11 tahun 2006 Tentang Pemerintahan Aceh. Pemerintahan Aceh. Aceh.
Indonesia, Undang-undang No. 33 tahun 2004 Tentang Perimbangan Keuangan antara Pemerintah Pusat dan Daerah. Sekretariat Negara, Jakarta.

Mardiasmo, 2009. Manajemen Keuangan, Erlangga, Jakarta.

Soemitro, R., 1979. Dasar-dasar Hukum Pajak dan Pajak Pendapatan, Erlangga, Jakarta.

Soemito, R., 1991. Asas-Asas Hukum Perpajakan. Cetakan Pertama. Bandung: Binacipta. 